DOI: $10.14746 /$ bhw.2018.38.3

\title{
The formation of scientific and research andragogy centres in the Second Republic of Poland
}

\begin{abstract}
Shaping of andragogy scientific-research centres in the Second Polish Republic The article shows the process of the institutionalisation of Polish andragogy. The author discusses the development of the first scientific-research institutions that gave rise to andragogical research in the Second Polish Republic (1918-1939). The main attention is given to academic centres, their representatives and research carried out. The author shows also that though not universally, andragogy has won a place in the university scientific community.
\end{abstract}

Keywords: history of andragogy, adult education history, scientific-research centres

\section{Introduction}

For the development of any scientific discipline, it is extremely important to obtain institutional foundations, i.e. institutions of an academic, research, and popularisation nature, which gather around them a community of scholars and researchers focused on specific issues, shape the directions of research, and initiate the formation of the scientific discipline. In fact, it is only by obtaining such an institutional basis that a given discipline can be distinguished from other sciences that it is possible to prove its entry into the next, more mature phase of development. It is a rarely appreciated side of science, often overlooked in analyses. However, as Jerzy Szacki and Jan Szczepański emphasise, until a science creates an appropriate institutional basis, it is not a science in the full sense of the word and it collapses with the death of its pioneers ${ }^{1}$. In this context, I would like to look at the in-

1 J. SZACKI, Historia myśli socjologicznej. Vol. 1-2. Warsaw 1983; J. SZCZEPAŃSKI, Socjologia. Rozwój problematyki i metod. Warsaw 1969; N. KRAŚKO, Instytucjonalizacja socjologii w Polsce 1920-1970, Warsaw 1996. 
stitutionalisation of Polish andragogic research. This process dates back to the period before Poland gained independence. The first andragogic studies and reflections were carried out outside academic centres, mainly through educational associations, which, while conducting educational and cultural activities among adults, also undertook the first research and publishing works, including in particular magazines and popularisations in the field of andragogic thought. They were a kind of substitute for scientific and research institutions, and performed functions which are normally performed by the state, local governments or corporations of scientists. This pre-institutional stage in the development of andragogic thought culminates in the 1913 publication of the first andragogic textbook Praca oświatowa. Jej zadania, metody i organizacja [Educational work. Its tasks, methods and organisation $]^{2}$.

The first andragogic scientific and research institutions were not established in Poland until after independence was regained. Andragogy, although not universally, has won a place in university scientific circles, and has created institutions deliberately established for its research and popularisation needs. In independent Poland, it is possible to speak about shaped scientific and research environments.

The aim of this article is to show the process of institutionalisation of Polish andragogy. On the one hand, the justification for this topic lies in the significant achievements of the andragogic thought of the Second Republic of Poland, and, at the same time, a rather low awareness of these achievements among contemporary andragogy researchers. In andragogy publications, including books on andragogy and even on the history of upbringing/education, there are no references to the achievements of Polish andragogy, and all the more so there is no mention of andragogy scientific-research institutions. We do not have a common social memory of the roots of Polish andragogic reflection; we can even speak of collective oblivion, or at least of a forgotten history. The drastic shortening of the timescale for reflection to only recent facts, situations and beliefs means that social memory is/ will be dead ${ }^{3}$. Thus, the centenary of independence of the Polish state is, we believe, an excellent opportunity to bring this achievement closer to contemporary readers. As Barbara Szacka convincingly argues, what we tell about our own past, what significance we attach to it, what interpretations of narratives about the past we consider to be our own, significantly defines the present and determine the future ${ }^{4}$.

\footnotetext{
2 Praca oświatowa. Jej zadania, metody, organizacja. The textbook was prepared by the effort of the Adam Mickiewicz People's University. By: T. BOROWSKI, Z. DASZYŃSKA-GOLIŃSKA, J. DZIUBIŃSKA, Z. GARGAS, M. HEILPERN, Z. KRUSZEWSKA, L. KRZYWICKI, M. ORSETTI, H. ORSZA, St. POSNER, M. STĘPOWSKI, T. SZYDŁOWSKI, Wł. WEJCHERT-SZYMANOWSKA. Kraków 1913. Published by Michał Arct in Warsaw. For more, see: A. STOPIŃSKA-PAJĄK, Powrót do źródła - o pierwszym polskim podręczniku andragogiki, Rocznik Andragogiczny 2012, Toruń 2012; and: Biograficzne konteksty pierwszego polskiego podręcznika andragogiki, Edukacja Dorosłych 2010, no. 2 (63).

${ }^{3}$ B. SZACKA, Czas przeszły, pamięć, mit, Warsaw 2006; Z. KWIECIŃSKI, Pedagogiczne aspekty wyzerowania [in:] Człowiek i edukacja, (Ed.) E.A. WESOŁOWSKA, Płock 2004.

${ }^{4}$ B. SZACKA, Przeszłość i interpretacje. Z warsztatu historyka filozofii, Warsaw 2015.
} 


\section{Andragogy in academic institutions of the Second Republic of Poland}

When attempting to present the centres that shape andragogic thought and research in Poland in the 1918-1939, it should be stated that not all of them should be treated equally. Their contribution to the development of research on adult education was diversified, based also on different theoretical and methodological assumptions. Undoubtedly, among the academic circles, Warsaw and Poznań were the most significant, where andragogy found the space and atmosphere for development, although in others, actions were taken in this respect as well.

\section{a) The Warsaw academic community}

The most serious centre for shaping andragogic thought and for developing its theoretical premises was the Free University of Poland (Wolna Wszechnica Polska, hereinafter referred to as WWP), a non-public higher education institution established in Warsaw in 1918. The merits of the WWP for the development of many humanities, social and natural sciences cannot be overestimated. In the andragogic context, the WWP should be treated as a university that was a pioneer of higher education for adults. Thanks to its organisation, structure, research and educational offer, it was a university that created conditions for study for all those who had the appropriate competences, regardless of formal certificates, and therefore it was possible for people without the matura diploma to take up their studies. The mission of WWP, as we would call it today, was to perceive its role mainly as an institution that fostered the development of sciences and popularised the passion for them $^{5}$. Moreover, in accordance with the statutes of WWP, the students had their representatives in the General Scientific Council, the highest legislative authority of the university $^{6}$, they participated and co-decided in the most important decisions, ahead of not only Polish, but also foreign universities in this respect ${ }^{7}$. The participation of student representatives was further strengthened by the creation of the Inter-faculty Academic Committee, as a representation of students who not only gave opinions, but also co-decided practically on every issue, starting from the social issues, through the verification of admissions to the university, as well as on the appointment of faculties and research laboratories, reorganisation of the functioning of faculties. Apart from lectures for students, WWP also conducted free Sunday single lectures for anyone interested.

It is also worth mentioning that the pedigree of this university, important for the development of science in Poland, dates back far into the past and stems from the self-education movement of the second half of the 19th century, founded on the basis of which the Flying University, which later in 1905 provided the basis for the launch of the Society of

${ }^{5}$ R. BŁĘDOWSKI, Jakjest przyszłość Wolnej Wszechnicy Polskiej, [in:] Ex Litteris Libertas. Jednodniówka Studentów Wolnej Wszechnicy Polskiej w Warszawie. Editorial Committee: Tomasz PISKORSKI, Mieczysław TYLL, Janina ZAWISTOWSKA. Ed. Tomasz PISKORSKI, Warsaw 1923.

${ }^{6}$ I. MYŚLICKI, Wolna Wszechnica Polska w obecnym jej stanie, [in:] Ex Litteris Libertas... .

${ }^{7}$ H. HEJDUKOWSKA-SADKOWSKA, Młodzież a Wolna Wszechnica Polska, [in:] Ex Litteris Libertas... . 
Scientific Courses, which became the direct beginning of the WWP ${ }^{8}$. Stanisław Kalinowski wrote: "The WWP dates back to the turbulent atmosphere of 1905. Its birth is one of the stages of the struggle which Polish society (unfortunately not all of it) waged against the Russian school at the time, creating a public Polish education instead of the secret one and voluntarily renouncing all the rights that governmental universities provided." $\mathrm{As}$ R. Błędowski put it, the Society of Scientific Courses was a kind of "ambulance service,"10 due to the lack of education opportunities in Polish universities and, above all, the limitations of higher education for women. It was in the environment of the Society that the programme and organisational concept as well as the basis for the activities of the WWP ${ }^{11}$ were developed. Thus, from the beginning of its existence, the WWP was an institution of education for adults. It is not surprising, therefore, that it was in this university that andragogic research found the best climate for development. It was in the WWP, among other faculties, that the first pedagogical faculty in Poland was launched, where research was carried out on the then new sub-disciplines of pedagogy, such as social pedagogy and andragogy, which were not recognised by other universities.

Interest in andragogic issues found many supporters at the WWP almost from the very beginning. In 1922, for the first time, lectures on out-of-school education began there. The initiator and creator of Polish andragogy, Helena Radlińska, recognised this moment as very important for the development of andragogy. At the same time, she stressed that recognition of adult education and upbringing as a subject of scientific research and regular studies - also at the WWP, very open to various novelties - had to be obtained through hard work and learning ${ }^{12}$. Since then, the andragogic issue has been permanently introduced into the study and research programme, strengthened by the establishment of the Centre for Social and Educational Work in 1924, headed by H. Radlińska until $1944^{13}$. It was a significant event for the development of andragogic thought and for the development of andragogy as a science. This is because the first Polish research and development centre for adult education and employee training had been established for the purpose of educational practice with adults. The Centre developed an original concept of teaching educational staff, which placed great emphasis on theoretical psychological, pedagogical and sociological knowledge and on shaping the students' skills of self-education and research

${ }^{8}$ L. KRZYWICKI, Wykłady latajace. (Poprzednicy Wolnej Wszechnicy Polskiej), [in:] Ex Litteris Libertas... . ; S. KALINOWSKI, Racja bytu Wolnej Wszechnicy Polskiej, [in:] Ex Litteris Libertas... .

9 S. KALINOWSKI, Racja Bytu Wolnej Wszechnicy Polskiej, [in:] Ex Litteris Libertas ... , p. 10.

${ }^{10}$ R. BŁĘDOWSKI, Jak jest przyszłość Wolnej Wszechnicy Polskiej, [in:] Ex Litteris Libertas ... , p. 32.

${ }^{11}$ Dziesięciolecie Wolnej Wszechnicy Polskiej. Sprawozdanie z działalności Towarzystwa Kursów Naukowych 1906-1916. Contributors: Ryszard BŁĘDOWSKI, Henryk CZOPOWSKI, Ignacy HALPERN, Piotr HOSER, Stefan MOSZCZEŃSKI, Henryk MOŚCICKI, Wacław WERNE, Ed. Stanisław ORŁOWSKI, Warsaw 1917.

${ }^{12}$ H. RADLIŃSKA, Listy o nauczaniu i pracy badawczej, [in:] Z dziejów pracy społecznej i oświatowej, Wrocław-Warsaw-Kraków 1964.

13 Among others, see W. THEIS, Wanda Wyrobkowa-Pawłowska: życie jako służba społeczna, Pedagogika Społeczna 2017, no. 1 (63). 
work. It was an original educational concept, which, as H. Brodowska writes, gained recognition in the international typology of faculties and schools of educating socio-educational workers as the "Warsaw School"14.

At the Centre, research on various andragogic issues was undertaken, both in the basic didactic course, as well as in the proseminars and seminars. It should be noted that these classes served at least two functions. On the one hand, they educated students and deepened their specialised preparation; on the other hand, they were specific research teams dealing with andragogic issues, overlooked by other scientific circles. It is extremely significant that the participants of the research teams were both academic staff, as well as students, graduate students and alumni of the Centre. Such a composition of seminar members - theorists and practitioners - allowed for the creation of scientific-research teams for environmental research, at the same time enabling cyclical, longer studies with broader range. The seminars most fully reflect the directions of research developed at the Centre, and thanks to their personal connection with specific scientists and researchers, they show the thematic and methodological diversity of the research carried out. Often, the same issues were developed in several seminars, which allowed for a more comprehensive approach and understanding. At this point, it is also worth emphasising the fact that there were two chairs of sociology in the WWP, with scholars of such calibre as Ludwik Krzywicki (1859-1941), Stefan Czarnowski (1879-1937) and Józef Chałasiński (1904-1979) associated with them. The works of these scholars, showing the socio-cultural contexts of the formation of human personality, significantly influenced the presentation of basic andragogic concepts.

The greatest contribution to the development of andragogic research and to the development of andragogy was made by Helena Radlińska, who since 1926 conducted the first of several her own Out-of-School Education Seminars at the Centre. Within the framework of this seminar, research was undertaken in various fields: historical, forms of work in out-of-school education, reading, social services.

Historical topics developed by the participants of the classes on the history of educational work focused on two cycles of issues. The first covered the period of the Congress Kingdom, the second - the period of open and conspiratorial educational works at the turn of the 19th and 20th centuries. In the first cycle, the activities of Stanisław Staszic were mainly examined, which certainly resulted from $\mathrm{H}$. Radlińska's interest in his figure. Radlińska was pursuing habilitation on the basis of the Staszic as a social activist dissertation. Using very diverse and rich archival materials, the scholar showed Staszic as a socioeducational activist, a practitioner. It was an innovative approach at the time, combining this trend of research with Radlińska's earlier pioneering studies on the past of social and educational work ${ }^{15}$. Polish historiography at the time did not contain any studies of the history of out-of-school and adult education. The research developed at the Centre was there-

${ }^{14}$ H. BRODOWSKA: Z dziejów kształcenia pracowników społeczno-oświatowych, 1925-1932. Zeszyty Naukowe Uniwersytetu Łódzkiego Nauki Humanistyczno-Społeczne. Series I, bk. 10. Łódź 1958.

${ }^{15}$ H. RADLIŃSKA, Stanisław Staszic jako działacz społeczno-oświatowy, Polska Oświata Pozaszkolna 1926, no. 1. Idem., Staszic jako działacz społeczny, [in:] Stanisław Staszic 1755-1824. Księga zbiorowa. Ed. 
fore supposed to continue and expand previous research activities. This is evidenced by the Staszic-themed dissertations of seminar participants - Jadwiga Brzozowska, Elżbieta Czapska, Stanisław Tołwiński. This series also includes a dissertation on M.S.F. Grundtvig by seminar assistant Zofia Gulińska.

The second series was more extensive. Unfortunately, few works were printed, some of them were destroyed by fire during World War II. Among the published works, one can mention: S. F. Reymont: Życie i działalność Konrada Prószyńskiego (K. Promyka), published after World War II in 1948, Z Żarnecka: Działalność oświatowa Faustyny Morzyckiej (published after the war in 1948), I. Mackiewicz-Wojciechowska: Uniwersytet “Latajacy.” Kartka z dziejów tajnej pracy oświatowej, as well as H. Radlińska and Balbina Śliwińska: Walka o duszę ludu. Z ziemi płockiej w latach 1864-191316.

A theoretical summary of the historical and educational works was a dissertation by H. Radlińska, Program i metoda badania dziejów pracy oświatowej. I. Kongresówka $w$ drugiej połowie XIX wieku [Programme and method of researching the history of educational work. I. Congress Poland in the second half of the 19th century] as well as Stawianie zagadnień $w$ badaniach nad najnowszymi dziejami pracy kulturalnej [Raising questions in studies on the latest history of cultural work]. Both works are the first methodological studies of this type, outlining the programme and directions of the necessary research. As Radlińska wrote, the research on the educational past is aimed at showing the significance and influence of individuals and institutions on activating the educational needs of adults and helping them to develop.

In the following years, Radlińska conducted three different seminars simultaneously: on the history of social and educational work, on research methods for disseminating reading and popularization, and on social service. Research on readership conducted by Radlińska and her students covered such issues as: life stages and mental age in relation to readership, the influence of culture on the development of readers' interests, the influence of the environment and home and school conditions, etc. on the development of interest among readers from various social groups. Special attention was paid in the research to the importance and participation of cultural and educational institutions and adult educational institutions in the development and shaping of reading interests. The researchers used methods of sociology, psychology, statistics and adapted them to the needs of the studies. The scholars demonstrated that if the reading process is a physiological-psychological one, the process of readership is already socially and economically determined. This was confirmed by research and works of Aniela Marczakowa, Zofia Hryniewicz, J. ZarębaGuzińska, which showed the importance of environmental factors in the educational processes of adults. In addition to contributing to the theoretical body of work on the theory of adult education, the work by Radlińska’s assistant, Irena Drozdowicz-Jurgielewicz, en-

\footnotetext{
Z KUKULSKI, Lublin 1928. This work also includes the dissertations of seminar participants J. BRZOZOWSKA, E. CZAPSKA and S. TOŁWIŃSKI on Staszic.

16 The manuscript of the work was destroyed by fire during the Warsaw Uprising. Its fragments were published in a collective work: H. RADLIŃSKA, Materiaty do dziejów walki o duszę ludu (1864-1913), [in:] Studia z dziejów kultury polskiej, Warsaw 1949.
} 
titled Upodobania czytelnicze dorostych [Adult readership preferences] (Warsaw 1939), also contributed to the knowledge of the reception of a literary work. It is worth mentioning that this research was initiated and conducted together with the Institute of Adult Education, which also published the book. Drozdowicz-Jurgielewicz's work contributed to the emerging knowledge about the reception of a literary work, and also contributed to the theoretical output of andragogy. The research showed that adults demonstrated sufficient mastery of reading techniques, as well as aesthetic illiteracy, which was manifested by a complete lack of sensitivity to the literary form and aesthetic values of the work. Moreover, the results of the research confirmed the dependence of adult readers' interests on environmental incentives and technical accessibility of the book.

The discussed research is synthesised by H. Radlińska in the excellent Ksiażka wśród $l u d z i$, which was reprinted four times ${ }^{17}$. Based on the results of her own research and that of her collaborators, Radlińska presented the role of the book as the main factor shaping human spiritual development. The work combines theoretical considerations with praxeological guidelines for adult teachers and educators. It shows numerous examples of the use of the book in adult education, in the development of their independence and self-creative use. It is also worth noting that this work reflects the influence of cultural pedagogy on the recognition and interpretation of andragogic phenomena. Ryszard Wroczyński emphasised in particular the connection between H. Radlińska's reflections and the pedagogy of culture. He wrote: “[...] the role of Helena Radlińska’s Książa wśród ludzi could be compared - in a general way - to that of Bogdan Nawroczynski's Zasady nauczania. The former indicated the following relations: culture - upbringing in the current of cultural work; the latter - in the process of upbringing of the young generation in the school system"18. Radlińska wrote that the book belongs to the concept of Homeland and forms its community. The significance and role of the book goes far beyond the current needs and this is what Radlińska considered to be its creative value. She wrote: "The values forgotten at a given moment are abandoned, live on in the book and will be resurrected within it. There is hidden power in it, which will appear in an unforeseen moment of need, flourishing with the creativity of tomorrow"19.

There were also other seminars at the Centre, and I would like to draw your attention to those that dealt with andragogical issues. Since the 1928/1929 academic year, a seminar entitled "Studies of the working life" was offered by Konstanty Krzeczkowski (1879-1939). He was a scholar of high calibre, a professor at the Warsaw School of Economics, who influenced students and employees of the Centre, as well as Radlińska herself. Krzeczkowski was a person of great merit for the development of Polish adult education, involved in the work of the Adam Mickiewicz People's University in Warsaw an activist in the Free Reading Room of the Warsaw Charitable Society, was also the secretary of the

${ }^{17}$ H. RADLIŃSKA, Książka wśród ludzi, Warsaw 1929; 2nd edition, expanded Warsaw 1934; 3rd edition, supplemented, Lviv 1938; 4th edition, amended, Warsaw 1946.

18 R. WROCZYŃSKI, Pedagogika społeczna Heleny Radlińskiej na tle polskiej myśli wychowawczej Drugiej Rzeczypospolitej, Człowiek w Pracy i Osiedlu 1980, no. 2-3, pp. 18-19.

${ }^{19}$ H. RADLIŃSKA, Książka..., Warsaw 1946, p. 16. 
editorial office that published the world's unique publication Poradnik dla samouków [The Self-Taught Guide]. Krzeczkowski raised the importance of the social and economic conditions of adult education and appreciated the role of social and educational institutions that support the strength of individuals. Radlińska wrote: "Krzeczkowski placed particular emphasis on organisation, laws and equipment, while I focused on the ability to identify needs, awaken and teach how to create institutions and how to use them ${ }^{20}$.

The social and educational seminar was led by Kazimierz Korniłowicz (1892-1939), an active educational activist, the initiator and ideologist of day-rooms, and an employee of the Centre. He took up new andragogic issues concerning social problems of upbringing of adults. He devoted a lot of attention to the issue of free time, the so-called adult holidays. He developed his own creative concepts of cultural and educational work among adults, based on comparative studies. Korniłowicz combined the needs of practical training with scientific and research activities. Under his direction, in 1927, a day-room seminar was established for graduates of the Centre working in Warsaw's day-rooms. His activities also resulted in publications presenting the activities of day-rooms, as well as foreign forms of adult education. On the basis of his research, Korniłowicz created an original concept of cultural and educational work among young people and adults, which he understood as "help in creating." It was a trailblazing concept, pioneering in Polish andragogic thought, appreciating the creative side of adult education. Unfortunately, it should be noted that it is too little known and developed in Polish reflection, including andragogic thought ${ }^{21}$.

The seminar was attended by Helena Pleszczyńska, Korniłowicz's assistant and longterm collaborator, who was interested in cultural and educational work in the urban environment - she presented the results of her research in the work Miejska młodzież pracujaca a świetlice [City working youth and day-rooms] (Warsaw 1933); she was also the author of a study presenting various forms of educational work carried out in Poland ${ }^{22}$. Władysław Radwan (1884-1963), who conducted research on people's universities, was also associated with the Korniłowicz seminar. The issue of the educational role of the boarding people's schools was also the subject of a seminar conducted by Eustace Nowicki (1885-1954).

The seminar on teaching methods was led by Marian Bronisław Godecki (1888-1941), an educational activist and author of many publications on adult education.

The group of scientists connected with the Centre, either through seminars or by conducting various other forms of didactic and scientific research, was much wider. The framework of the article does not allow for presenting all these figures. It is worth men-

${ }^{20}$ H. RADLIŃSKA, Listy o nauczaniu i pracy badawczej, [in:] Z dziejów pracy społecznej i oświatowej, Wrocław-Warsaw-Kraków 1964, p. 434.

${ }^{21}$ For more, see A. STOPIŃSKA-PAJĄK: Koncepcja kreatywnego wychowania dorostych Kazimierza Korniłowicza (1892-1939), [in]: Andragogiczne wątki. Poszukiwania. Fascynacje. (Ed.) E. PRZYBYLSKA. Toruń 2001.

${ }^{22}$ H. PLESZCZYŃSKA, Formy pracy kulturalno-oświatowej w Polsce, [in:] Przewodnik oświaty dorostych (1928). (Ed.) A. KONEWKA, K. KORNIŁOWICZ, Warsaw 1929. 
tioning, however, the names of the most significant ones for the development of andragogic thought, who, as H. Radlińska put it, brought valuable scientific or practical values and laid the foundations for the development of andragogic thought and theory. These included Jan Muszkowski (1882-1952), Jan Strzelecki (1890-1944), Józef MikułowskiPomorski (1868-1938), Stanisław Rychliński (1903-1944), Maria Lipska-Librachowa (1878-1955), Józef Chałasiński, Stefan Czarnowski, Bogdan Suchodolski (1903-1992), Sergiusz Hessen (1887-1950), Albert Dryjski (1889-1956), Czesław Babicki (1880-1952), Janusz Korczak (1878-1942) and many others.

The research and educational activity of the Centre at the WWP and the scientists and researchers associated with it created the basis and conditions for the formation of Polish andragogy. It should be stressed that participation in various teaching and research activities of many scientists - eminent individuals and professors, also from other universities and socio-educational activists - connected the university with other scientific, educational, research and advisory institutions. Personal relationships made it possible to conduct joint research, which in the period of the Second Republic of Poland was quite a rare phenomenon, and above all they allowed for the presentation of andragogy issues from the perspective of different disciplines and different methodological standpoints ${ }^{23}$.

It should also be noted that the scientists working in the Centre, and especially Helena Radlińska, maintained close contacts with foreign scientific centres, participated in various conferences, conventions, scientific travels, etc., and established international cooperation in the field of adult education.

At the University of Warsaw, issues of andragogy were not addressed. Although it was a university where pedagogical education and research were carried out, the main focus was on school issues. However, the work and research undertaken there, especially focused around Bogdan Nawroczyński, head of the Chair of Pedagogy, established in 1926, gave rise to the formation of andragogical thought. In many andragogic studies we find much evidence of drawing on Bogdan Nawroczyński's theoretical and methodological position.

Among Warsaw's universities, the Warsaw University of Life Sciences, which has a long tradition dating back to the early 19th century (1816), played a rather significant role in the development of andragogy, and in particular its agricultural andragogy sub-discipline. The issues discussed there related mainly to theoretical and methodical aspects of popularisation and dissemination of agricultural education among adults. There was also a course of social agronomy for graduates - farmers who took up employment in agricultural education, or in out-of-school education in rural areas. This issue was reflected in the publications of Władysław Grabski, ${ }^{24}$ Władysław Bronikowski, ${ }^{25}$ and especially Józef

${ }^{23}$ A. STOPIŃSKA-PAJĄK, Andragogika w Drugiej Rzeczypospolitej. Warunki rozwoju. Problematyka. Koncepcje. Katowice 1994.

${ }^{24}$ W. GRABSKI, Kultura wsi polskiej i nauczanie powszechne, Warsaw 1929; Idem, Oświata ludu i sprawy agrarne $w$ Polsce, Warsaw 1929.

25 W. BRONIKOWSKI, Drogi postęu chłopa polskiego, Warsaw 1934. 
Mikułowski-Pomorski, ${ }^{26}$ the first rector of the WULS, who, as I have already mentioned, was also scientifically active in the Higher School of Education. The emergence of andragogic issues in a university with an agricultural profile is proof of recognition not only of the need for agricultural education, but also of the need for research and dissemination of knowledge on methods and forms of its implementation among adult inhabitants of rural environments ${ }^{27}$. The research initiated in this area provided a scientific basis for the development of the theory of out-of-school agricultural education, i.e. agricultural andragogy.

Another university where andragogic issues were recognised was the Institute of Pedagogical Sciences of the Union of Polish Teachers (ZNP), established in Warsaw in 1932. It was the first academic school for teachers. One of the tasks of the Institute was to prepare teachers for social and educational work. The Institute operated two faculties: pedagogical and social. Social science subjects were included to a large extent within the training programme framework. They included organisation of forms and methods of social work in Poland and abroad, social and economic legislation and, above all, it is worth recalling those run by Józef Chałasiński, the head of the social faculty, such as school and society, the social function of school, village and city in educational work. The aim of education at the Institute was to shape teachers' beliefs in the need of social and educational work and to shape active attitudes towards social and educational life. At various times, scholars and researchers of adult education issues were associated with the Institute, among others Władysław Okiński, Jerzy Cierniak, Kazimierz Maj, Stanisław Bystroń and Bogdan Suchodolski.

\section{b) The Poznań academic community}

Apart from the Warsaw scientific community, as I have already written, the Poznan scientific community also held a significant place. It should be noted that it was in Poznań, at the University of Poznań, established in 1919 (initially under the name of Wszechnica Piastowska), that andragogic subjects were introduced into the curriculum, intended to prepare students for educational work with adults in various environments. Starting in the $1929 / 1930$ academic year, a lecture on adult teaching methodology was introduced for students of pedagogy and made available to students of all faculties, which is particularly worth appreciating. The lecture was conducted by Andrzej Niesiołowski (1899-1945), a doctor of philosophy and well-known educational activist. The programme of the lecture included, among others, the following content: objectives and forms of educational work, adult psychology, environmental theory, self-education team, emotional shaping of adults, sociology of adult education ${ }^{28}$. It was a recognition that andragogic knowledge is

\footnotetext{
26 J. MIKUŁOWSKI-POMORSKI, Oświata rolnicza pozaszkolna, Warsaw 1934; Idem, Czym jest przysposobienie rolnicze, Warsaw 1935.

27 Zob. T. WIECZOREK, Ksztatcenie rolnicze w Polsce Ludowej, Warsaw 1972; Cz. MAZIARZ, Andragogika rolnicza, Warsaw 1984.

${ }_{28}$ Among others, see Uniwersytet Poznański. Spis wykładów i skład uniwersytetu za rok akademicki 1932/33, Poznań 1932; Uniwersytet Poznański. Skład Uniwersytetu i spis wykładów na rok akademicki 1934/35. Poznań 1934.
} 
needed not only by the teacher, but also by other professionals. It is worth quoting the justification of the advisability of launching such a lecture, which is still very timely today: "This reform aims to assist the intelligentsia of all professions in obtaining general preparation for educational work, which can take the form of voluntary civic service or a secondary profession. The idea is that not only teachers, but also doctors, lawyers and agronomists should be able to take from the university the preparation for the educational work, which today cannot be practised in a dilettante manner ${ }^{29}$.

In 1937, the Out-of-School Education Centre of the University of Poznań was launched, intended for future specialist educators ${ }^{30}$. Students could enrol at the Centre in the second year of pedagogy and the programme was planned to last 3 years. The Centre was also open to students of other faculties for whom pedagogy was a side subject. The aim of the centre was to prepare out-of-school education instructors, teachers of pedagogical secondary schools, managers and teachers of open universities and people's universities. The curriculum included the history of out-of-school education, the teleology of outof-school education, forms of educational work in Poland and abroad. Each unit was also linked to a relevant mandatory seminar.

The introduction of andragogic issues into the range of subjects taught systematically at the University, mainly on the initiative of the then Dean of the Faculty of Humanities, Ludwik Jaxy-Bykowski (1881-1948), put the Poznań centre first in Poland and second in Europe - after Leipzig. Andrzej Niesiołowski explained that universities neglected this important field of adult education. The reasons he listed for this delay included: overly delayed, also in Europe, understanding of the importance of upbringing, the persistence of the belief that adult education was easier than children's education, the lack of scientific andragogy autonomy. Niesiołowski wrote that andragogy, just like pedagogy, "as a discipline of primarily practical nature (not only because adult education can be treated descriptively, as a social fact) does not have a scientific method specific only to it and necessarily constitutes an area of cooperation of various independent sciences, which are here in a supporting capacity" ${ }^{31}$. Among these auxiliary sciences he mainly included psychology and sociology. In his opinion, however, in the field of adult education - more than in pedagogy - sociology comes to the fore. He wrote: "It enables us, first of all, to systematically present individual forms of educational work and their social and organizational structure, as well as to analyse the methods of impact and types of reactions" ${ }^{\prime 32}$.

The introduction of andragogy classes into the curriculum was therefore undoubtedly connected with the fact that Poznan was where a significant sociological centre was developed, and where a sociological school was established, which under the direction of Florian Znaniecki was given institutional foundations. The works by sociologists, es-

${ }^{29}$ A. N.: Z instytucji: Uniwersytet Poznański. Studium Oświaty Pozaszkolnej, Praca Oświatowa 1937, no. 9 , p. 544.

${ }^{30}$ List of lectures for the 1937/1938 academic year. \{University of Poznań\}. Poznań 1937.

31 A. NIESIOŁOWSKI, Formy i metody pracy oświatowej. Próba klasyfikacji i analizy socjologicznej, Warsaw 1932, p. 4.

${ }^{32}$ A. NIESIOŁOWSKI, Formy i metody ..., p. 4. 
pecially in the then new sub-discipline - the sociology of upbringing (F. Znaniecki, J. Chałasiński) - described upbringing as a social process, also going on outside school and belonging to the phenomena of cultural life. The introduction by sociology of a broad approach to the concept of upbringing was extremely beneficial for the development of andragogic thought. It made it possible to link andragogic phenomena with social problems of the environment and, at the same time, to include them in a cultural context.

As a result of sociology's interest in andragogic issues, several dissertations significant for the development of andragogy were published. Among them, the first one to be mentioned is the dissertation by Florian Znaniecki, who was one of the first in Poland to present the concept of adult upbringing. In a paper delivered at an educational conference in 1929, entitled "Podstawy i granice celowego działania wychowawczego" [The basics and limits of intentional educational activity $],{ }^{33}$ he expressed his belief that only adults can be the subjects of intentional educational interactions.

From the sociological point of view, Władysław Okiński (1906-1944) addressed the issues of self-education and open university, as well as developed a theoretical classification of forms of educational work ${ }^{34}$. Moreover, Marian Wachowski (1903-1970) and Andrzej Niesiołowski focused their scientific and research work mainly on andragogic issues $^{35}$. A. Niesiołowski in his work Formy i metody pracy oświatowej. Próba klasyfikacji $i$ analizy socjologicznej (Warsaw 1932) made the first attempt at a sociological systematisation of educational issues, and analysed this form of work from the sociological and personalistic point of view in the publication Kola oświatowo-wychowawcze Zadaniateoria - wskazania praktyczne [Educational and Educational Clubs. Tasks - theory - practical indications] (Poznań-Warsaw-Vilnius-Lublin 1939). It is worth stressing that these works were based on solid studies and comparative materials collected during a scientific journey around Europe. Marian Wachowski, in turn, analysed andragogic issues both from the theoretical point of view, in his work Prawo odpowiedniości $w$ wychowaniu szkolnym $i w$ oświacie pozaszkolnej [The Law of Suitability in School Education and in Extracurricular Education ] (Poznań 1930), and undertook sociological and pedagogical research, which found preparation in his works Problemy oświatowe robotnika wielkopolskiego [The Educational Problems of Wielkopolska Workers] (Poznań 1937) and Przygotowanie zawodowe robotnika rolnego w świetle pedagogiki empirycznej [The Professional Preparation of Agricultural Workers in the Light of Empirical Pedagogy] (Poznań 1939). Wachowski's works and activities initiated the formation of agricultural andragogy, also in the institutional dimension. The Faculty of Agriculture and Forestry was successful in launching a specialisation in teaching agriculture. It was headed by

${ }^{33}$ F. ZNANIECKI, Podstawy i granice celowego działania wychowawczego, [in:] Zagadnienia oświaty dorostych. Dwie konferencje, Warsaw 1930.

${ }^{34}$ W. OKIŃSKI, Procesy samokształceniowe. Próba ustalenia pojęcia samokształcenia ze stanowiska socjologii, Poznań 1935; Idem, Problemy spoleczne uniwersytetu powszechnego w Polsce, Warsaw 1938.

${ }^{35}$ A. STOPIŃSKA-PAJĄK: Andragogika w Drugiej... . 
M. Wachowski. The organisers wanted to prepare instructors of agricultural education to work in out-of-school education in rural areas ${ }^{36}$.

Starting in 1927, the Catholic Social School in Poznań, headed by Fr. Edward Kozłowski, operated in the Poznań community, mainly with the aim of educating activists of the Catholic educational movement. Although it was not an academic school, I mention it because its curriculum also included andragogic subjects, and the aim was to shape a socio-educational worker who uses scientific methods in their work. The school brought together excellent lecturers, scholars and researchers of educational phenomena. Among them one can mention such scientists as: Stefan Szuman, who lectured on general psychology, Józef Czesław Babicki, who lectured on the basics of community education, H. Radlińska, who lectured on out-of-school education, as well as A. Niesiołowski and M. Wachowski ${ }^{37}$.

\section{c) Other academic communities}

Another university centre where the issue of adult education was introduced into the curricula of pedagogical education was the Jagiellonian University, where since the 1934/1935academic year, a lecture on out-of-school education was launched at the Pedagogical Centre of the Faculty of Philosophy, entitled "Organisation of extracurricular education in Poland," taught starting in 1936/1937 by Maksymilian Siemieński (1905-1966), then an instructor of adult education at the Krakow School District's Board of Education $^{38}$. The lecture covered many issues related to adult education, and was supplemented by visitations and tours of out-of-school education institutions. The main goal of the classes was to awaken the interest of future teachers in andragogic issues.

In the 1938/1939 academic year, the Catholic University of Lublin launched a threemonth social course for educational staff. It is worth noting that it covered 480 hours of classes, including 120 hours of internship, and 23 employees, including 6 university professors, conducted the classes, while the issues related to out-of-school education covered 124 hours, although most of them were issues related to educational work among children and youth $^{39}$. However, I mention these activities as a proof of the gradual strengthening of understanding in academic circles of educating staff for the needs of out-of-school education.

An institution where no andragogic research was carried out, but which in the Second Republic was a rare example of a university for adults was the Institute of Pedagogy in Katowice was established in 1928. It provided training for active teachers. The educational programme also included the issues of socio-educational and out-of-school work.

${ }^{36}$ E. KOŁOWSKI, Pedagogika rolnicza i kształcenie nauczycieli w Poznaniu w latach 1920-1939, Przegląd Historyczno-Oświatowy 1980, no. 4.

${ }^{37}$ Fr. Dr E. KOZŁOWSKI, Katolicka Szkoła Społeczna w Poznaniu, [in:] Pracownik oświatowy. Bulletin of the 14th Education Conference devoted to the education of adult education staff, Warsaw 1930.

38 M.S., Uniwersytet Jagielloński. Wyktad 'Organizacja oświaty pozaszkolnej', Praca Oświatowa 1939, no. 4 .

39 J.K., Kurs społeczny przy Uniwersytecie w Lublinie, Praca Oświatowa 1939, no. 6. 
Scientists from Warsaw, Poznań and Krakow universities were connected with the Institute in various years.

To conclude the description of scientific research centres of andragogy in Poland in the interwar period, one should also note the interest in research on adult education among Polish psychologists. Although the achievements of Polish psychologists of that period are significant, research on the psychological aspects of adult education was undertaken to a small extent. However, there were publications, mainly articles and dissertations, devoted to these issues, which were the result of individual research interests of several psychologists. These include Maria Lipska-Librachowa (1878-1955), a worker of the WWP, Józefa Joteyko (1866-1928), Leopold Blaustein (1905-1942/1944), Stefan Baley (1885-1952) and Stefan Szuman (1889-1972) ${ }^{40}$.

Other important andragogic centres in the Second Republic of Poland included educational societies, socio-educational organisations and numerous social-educational and andragogic journals. They brought together practitioners, adult education activists as well as theoreticians and researchers. They provided a platform for mutually beneficial cooperation, initiation and popularisation not only of various forms of educational and upbringing work with adults, but also for research on adult education and andragogic thought. This is a subject for a separate article; however, I mention it because a characteristic feature of the institutionalisation of Polish andragogy was the close cooperation of the academic and non-academic circles.

\section{Conclusions}

The considerations presented in the article allow us to state that in the Second Republic of Poland, andragogy entered the scientific phase of development, gained recognition among other disciplines dealing with research on upbringing. During this period, andragogy shaped the subject of research, brought together scientists and researchers, gained an institutional basis for research and education of teachers of adults, and finally, undertook theoretical and methodological analyses of its own discipline. A characteristic feature of the andragogy emerging in the Second Republic of Poland was the use of many disciplines, in particular social pedagogy, cultural pedagogy, psychology and sociology, to interpret and understand the problems of education and upbringing of adults. It therefore developed as an interdisciplinary, multiparadigmatic science. This methodological characteristic of the andragogy of the period in question contributed to its rapid development and recognition as a science dealing with the problems of adult education, teaching and learning. In a short period of twenty years, it accumulated a significant theoretical output,

${ }^{40}$ See, inter alia M. LIPSKA-LIBRACHOWA, Dorosty a dziecko, [in:] Yearbook of Courses for Adults, Vol. 2. Warsaw 1920; J. JOTEYKO, Znaczenie wrażeń wzrokowych wnauczaniu dorostych, Oświata Pozaszkolna 1921, bk. 1-2; L. BLAUSTEIN, Psychologiczne podstawy oświaty pozaszkolnej, Warsaw 1935; S. SZUMAN, Co to jest dojrzała psychika, Praca Oświatowa 1935, no. 1 and others. 
based on scientific foundations, which through application can and should be the basis for consideration and formulation of the concept of contemporary andragogists.

\section{Works cited}

BRODOWSKA H., Z dziejów ksztatcenia pracowników społeczno-oświatowych, 1925-1932. Zeszyty Naukowe Uniwersytetu Łódzkiego Nauki Humanistyczno-Społeczne. Series I, bk. 10. Łódź 1958.

KOŁOWSKI K., Pedagogika rolnicza i kształcenie nauczycieli w Poznaniu w latach 1920-1939, Przegląd Historyczno-Oświatowy 1980, no. 4.

KRAŚKO N., Instytucjonalizacja socjologii w Polsce 1920-1970, Warsaw 1996.

KWIECIŃSKI Z., Pedagogiczne aspekty wyzerowania, [in:] Człowiek i edukacja, (Ed.) E.A. WESOŁOWSKA, Płock 2004.

MAZIARZ Cz., Andragogika rolnicza, Warsaw 1984.

RADLIŃSKA H., Listy o nauczaniu i pracy badawczej, [in:] Z dziejów pracy społecznej i oświatowej, Wrocław-Warsaw-Kraków 1964.

STOPIŃSKA-PAJĄK A., Andragogika w Drugiej Rzeczypospolitej. Warunki rozwoju. Problematyka. Koncepcje. Katowice 1994.

STOPIŃSKA-PAJĄK A., Biograficzne konteksty pierwszego polskiego podręcznika andragogiki, Edukacja Dorosłych 2010, no. 2 (63).

STOPIŃSKA-PAJĄK A., Powrót do źródta - o pierwszym polskim podręczniku andragogiki, Rocznik Andragogiczny 2012, Torun 2012.

STOPIŃSKA-PAJĄK A., Koncepcja kreatywnego wychowania dorostych Kazimierza Korniłowicza (1892-1939), [in:] Andragogiczne watki. Poszukiwania. Fascynacje. (Ed.) E. PRZYBYLSKA. Toruń 2001.

SZACKA B., Czas przeszły, pamięć, mit, Warsaw 2006.

SZACKA B., Przeszłość i interpretacje. Z warsztatu historyka filozofii, Warsaw 2015.

SZACKI J., Historia myśli socjologicznej. Pt. 1-2. Warsaw 1983.

SZCZEPAŃSKI J., Socjologia. Rozwój problematyki i metod. Warsaw 1969.

THEIS W., Wanda Wyrobkowa-Pawłowska: życie jako stużba społeczna, Pedagogika Społeczna 2017, no. 1 (63).

WIECZOREK T., Ksztalcenie rolnicze w Polsce Ludowej, Warsaw 1972. 
